\title{
High temperature chemical aspects of waste disposal and environmental clean-up
}

\author{
Brian R Bowsher, Richard G J Ball and Ian R Beattie \\ AEA Technology, Winfrith Technology Centre, Dorchester, Dorset, DT2 8DH, UK
}

\begin{abstract}
Experimental studies are described to quantify high temperature chemical aspects of waste disposal and environmental clean-up. Two main facilities are considered:

Osprey: to characterize high temperature vapors,

Harrier: to quantify the treatment of radioactive waste in a molten metal environment

These facilities are supported by matrix isolation-infrared spectroscopy, thermal analysis (DTA/TG/EGA) and thermodynamic and kinetic modeling. Examples of treatment of various radioactive waste streams are described.
\end{abstract}

\section{INTRODUCTION}

High temperature processes have been used to treat waste for many years, with incineration a favored approach to dispose of hazardous waste. Such high temperature methods are characterized by significant volume reduction and decomposition of the toxic material into environmentally acceptable waste streams (1). Examples of incineration technologies which are commercially available include liquid injection, rotary kiln, multiple hearth, fluidized bed, molten salt, and co-incineration. Some of the characteristics of the different plant and their off-gas streams are summarised in Table I (from reference (2)). However, as environmental standards become increasingly demanding, there is an increasing need to demonstrate rigorous control of environmental emissions (2-3). These requirements have pushed the design of waste disposal processes to ever higher temperatures, or to methods to ensure greater mass transfer (effective residence/interaction time) - exemplified by routes using molten metals (4), or more rigorous treatment of off-gases. Many of these issues are of particular importance when considering the treatment of radioactive waste. Careful consideration of all waste streams can reduce waste volumes, thereby reducing costs and doses, whilst maintenance of the integrity of the waste stream minimises environmental emissions.

This paper focuses on recent experimental studies within AEA Technology to quantify high temperature chemical aspects of waste disposal and environmental clean-up. Two main facilities are described:

(i) Osprey: to characterize high temperature vapors,

(ii) Harrier: to quantify the treatment of radioactive waste in a molten metal environment.

Osprey incorporates a Jordan reflectron time-of-flight mass spectrometer and a pressure reduction system, enabling the chemical identities and release rates of vapors to be determined from a wide range of systems (including highly radioactive waste streams) and atmospheres at temperatures up to $2000^{\circ} \mathrm{C}$. Emphasis is given to the characterization of short-lived species that contribute either to enhanced releases of particular elements or play a significant role in high temperature corrosion. These high pressure mass spectrometric experiments are supported by matrix isolation-infrared spectroscopy and thermodynamic modeling studies.

Small quantities of various waste streams may be processed in the Harrier facility, involving treatment in a molten metal bath at temperatures up to $1600^{\circ} \mathrm{C}$. The partitioning behaviour between metal, oxide and gas phases can be quantified with detailed studies undertaken to characterize any vapor/aerosol emission. These studies are supported by thermodynamic and kinetic modeling together with differential thermal analysis/thermogravimetry/evolved gas analysis (DTA/TG/EGA) studies. Examples of treatment of various radioactive waste streams are described. 
TABLE I Sources and Characteristics of Off-Gas Streams (from reference (2))

\begin{tabular}{|c|c|c|c|c|c|c|c|c|c|c|c|c|}
\hline \multirow[b]{3}{*}{$\begin{array}{c}\text { Process } \\
\text { Plant }\end{array}$} & \multirow[b]{3}{*}{$\begin{array}{l}\text { Type of } \\
\text { Waste }\end{array}$} & \multirow{2}{*}{\multicolumn{10}{|c|}{$\begin{array}{l}\text { Inifet into he trealment gystem } \\
\text { Off. Ras composition (\% by weight) }\end{array}$}} & \multirow[b]{3}{*}{ Remarks } \\
\hline & & & & & & & & & & & & \\
\hline & & $\begin{array}{l}\text { Temper- } \\
\text { ature } \\
{\left[{ }^{\circ} \mathrm{C}\right]}\end{array}$ & $\mathrm{CO}_{2}$ & $\mathrm{O}_{2}$ & $\mathrm{H}_{2} \mathrm{O}$ & HCI & $\mathrm{SO}_{\mathbf{z}}$ & co & $\mathrm{NO}_{z}$ & $\begin{array}{l}\text { Hydro } \\
\text { carbons }\end{array}$ & $\begin{array}{c}\text { Partic } \\
\text { ullate } \\
\text { bad } \\
\text { modm } \\
\end{array}$ & \\
\hline $\begin{array}{l}\text { incineralor } \\
\text { contudled } \\
\text { air and } \\
\text { dight } \\
\text { excess air }\end{array}$ & $\begin{array}{l}\text { Solid } \\
\text { combus- } \\
\text { tible } \\
\text { waste }\end{array}$ & $800-1100$ & $10.0-11.0$ & $10.0-12.0$ & 5.0 & 0.20 .3 & $0.03-0.04$ & " & - & "** & $<150$ & $\begin{aligned} & *<100 \mathrm{mg} / \mathrm{m}^{3} \\
&\left(11 \% \mathrm{O}_{2}\right) \\
& * * \\
& * 50 \mathrm{mgmm}^{3} \\
&\left(11 \% \mathrm{O}_{2}\right)\end{aligned}$ \\
\hline $\begin{array}{l}\text { Incinerator } \\
\text { excess air }\end{array}$ & $\begin{array}{l}\text { Solid } \\
\text { combus. } \\
\text { tible } \\
\text { waste }\end{array}$ & $800-1100$ & $6-10$ & $10-14$ & 3.04 .0 & $\begin{array}{l}\max . \\
0.4^{*} \\
0.500 \\
\text { ppm } \\
\text { normai }\end{array}$ & $\begin{array}{l}\max \\
0.090 * * \\
0.200 \\
p p m \\
p 00 \text { mal } \\
\text { nom }\end{array}$ & $\begin{array}{l}35-60 \\
\text { ppm }\end{array}$ & $\begin{array}{l}\text { 65-180 } \\
\text { ppm } \\
\text { No }\end{array}$ & "* & $<1500$ & $\begin{array}{l}* \text { at high PVC- } \\
\text { content } \\
\text { ** at high } \\
\text { nubber } \\
\text { content } \\
\end{array}$ \\
\hline $\begin{array}{l}\text { Pyrolyer } \\
\text { contuolled } \\
\text { pyrolysis }\end{array}$ & $\begin{array}{l}\text { Solid } \\
\text { combus. } \\
\text { cible } \\
\text { waste }\end{array}$ & $850-950$ & $10.0-18.0$ & $10,0-12.0$ & 5.0 & $0.2-3$ & $0.03-0.04$ & - & - & ** & $<150$ & 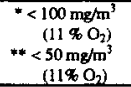 \\
\hline $\begin{array}{l}\text { Incinerator } \\
\text { excess air }\end{array}$ & $\begin{array}{l}\text { Liquid } \\
\text { combus. } \\
\text { tible } \\
\text { wastc }\end{array}$ & $900-1300$ & $10.0-11.0$ & $10.0-12.0$ & 3.04 .0 & - & - & * & $\cdot$ & $*$ & $<150$ & $\begin{array}{c}"<100 \mathrm{mg} / \mathrm{m}^{3} \\
\left(11 \% \mathrm{O}_{2}\right) \\
\cdots<50 \mathrm{mg}^{3} \mathrm{~m}^{3} \\
\left(11 \mathrm{~g} \mathrm{O}_{2}\right)\end{array}$ \\
\hline \multirow{2}{*}{$\begin{array}{l}\text { Pyrolyerr } \\
\text { themal } \\
\text { decompon } \\
\text { sition } \\
\text { without } \\
\text { addition of } \\
\text { oxygern }\end{array}$} & $\begin{array}{l}\text { Liquid } \\
\text { combus. } \\
\text { tible } \\
\text { waste }\end{array}$ & $300-500$ & & $\cdot$ & $10.0-15.0$ & $\cdot$ & & . & - & 50.060 .0 & $<5$ & $\begin{array}{l}\text { TBPI } \\
\text { dodecane }\end{array}$ \\
\hline & Resins & $300-500$ & - & - & 40.0 .50 .0 & - & $7.0-14.0$ & - & $1.0-1.5$ & $15.0-25.0$ & $<5$ & $\begin{array}{l}\text { Water content } \\
\text { in feed }-50 \% \\
\text { HCN product }\end{array}$ \\
\hline $\begin{array}{l}\text { Pyrohyd- } \\
\text { rolyser } \\
\text { controlled } \\
\text { pyrolysis } \\
\text { with air- } \\
\text { steam as } \\
\text { reaction } \\
\text { gas }\end{array}$ & $\begin{array}{l}\text { Solid } \\
\text { combus- } \\
\text { tible } \\
\text { waste (Pu } \\
\text { contenn) }\end{array}$ & $600-800$ & - & - & 40.0 .50 .0 & $1.0-10.0^{*}$ & $1.0-2.0$ & $5.0-10.0$ & - & 2.06 .0 & $<5$ & $\begin{array}{l}\text { High PVC } \\
\text { conient (up } \\
\text { to } 70 \% \text { ) }\end{array}$ \\
\hline $\begin{array}{l}\text { Slagging } \\
\text { pynolysis } \\
\text { incineralor }\end{array}$ & $\begin{array}{l}\text { Solid and } \\
\text { liquid } \\
\text { combus. } \\
\text { tobie } \\
\text { wastic }\end{array}$ & 1000 & & & & & & & & & $<25$ & $\begin{array}{l}\text { * Present when } \\
\text { PVC is } \\
\text { burned } \\
\text { ** from fuul } \\
\text { combustion } \\
\text { semivolatile } \\
\text { radionuclide } \\
\text { vapors } \\
\text { present }\end{array}$ \\
\hline $\begin{array}{l}\text { Fuidized } \\
\text { bed } \\
\text { incinerator }\end{array}$ & 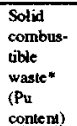 & 550 & $5-10$ & $8-10$ & & - & & $\begin{array}{l}75.500 \\
\text { ppm }\end{array}$ & $\cdot$ & $\begin{array}{l}50.500 \\
\text { ppm }\end{array}$ & $\begin{array}{l}<10 \\
\mathrm{ppm}\end{array}$ & 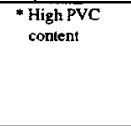 \\
\hline $\begin{array}{l}\text { Acid } \\
\text { digestion' } \\
\text { combus. } \\
\text { tion }\end{array}$ & $\begin{array}{l}\text { Solid } \\
\text { combus- } \\
\text { uible } \\
\text { wasie" } \\
\text { (Pu } \\
\text { content) }\end{array}$ & 250 & 10 & $<2$ & 20 & * & 30 & 2 & 30 & - & - & $\begin{array}{l}\text { * High PVC } \\
\text { content }\end{array}$ \\
\hline $\begin{array}{l}\text { Molien } \\
\text { sal } \\
\text { incinerator }\end{array}$ & $\begin{array}{l}\text { Solid } \\
\text { combus. } \\
\text { tible } \\
\text { waste }\end{array}$ & 800 & & & & & & & & & & $\begin{array}{l}\text { NaCl partides } \\
\text { acidic gases } \\
\text { contained in } \\
\text { mollen salt }\end{array}$ \\
\hline $\begin{array}{l}\text { Mollen } \\
\text { glass } \\
\text { incinerator }\end{array}$ & $\begin{array}{l}\text { Solid } \\
\text { combus- } \\
\text { tuble } \\
\text { waste } \\
\text { waste }\end{array}$ & $1200-1300$ & & & & & & & & & & \\
\hline
\end{tabular}

\section{EXPERIMENTAL FACILITIES}

\section{$\underline{\text { Osprey }}$}

The Osprey facility has been designed to determine the identity and magnitude of chemical species present at high temperatures by conducting in-situ measurements. The facility is used to characterize vapor emissions from a variety of high temperature, radioactive systems. Thus, it has been applied to study the speciation of fission products evolved from high burn-up fuel under a range of potential nuclear reactor accident conditions. It has also been used to determine the nature of emissions from a variety of radioactive waste streams under conditions simulating high temperature treatment.

Osprey achieves sampling from high temperature high pressure regions using a variety of small orifices and differential pumping (5). The key features are shown in Figure 1 and are summarised below (6). 


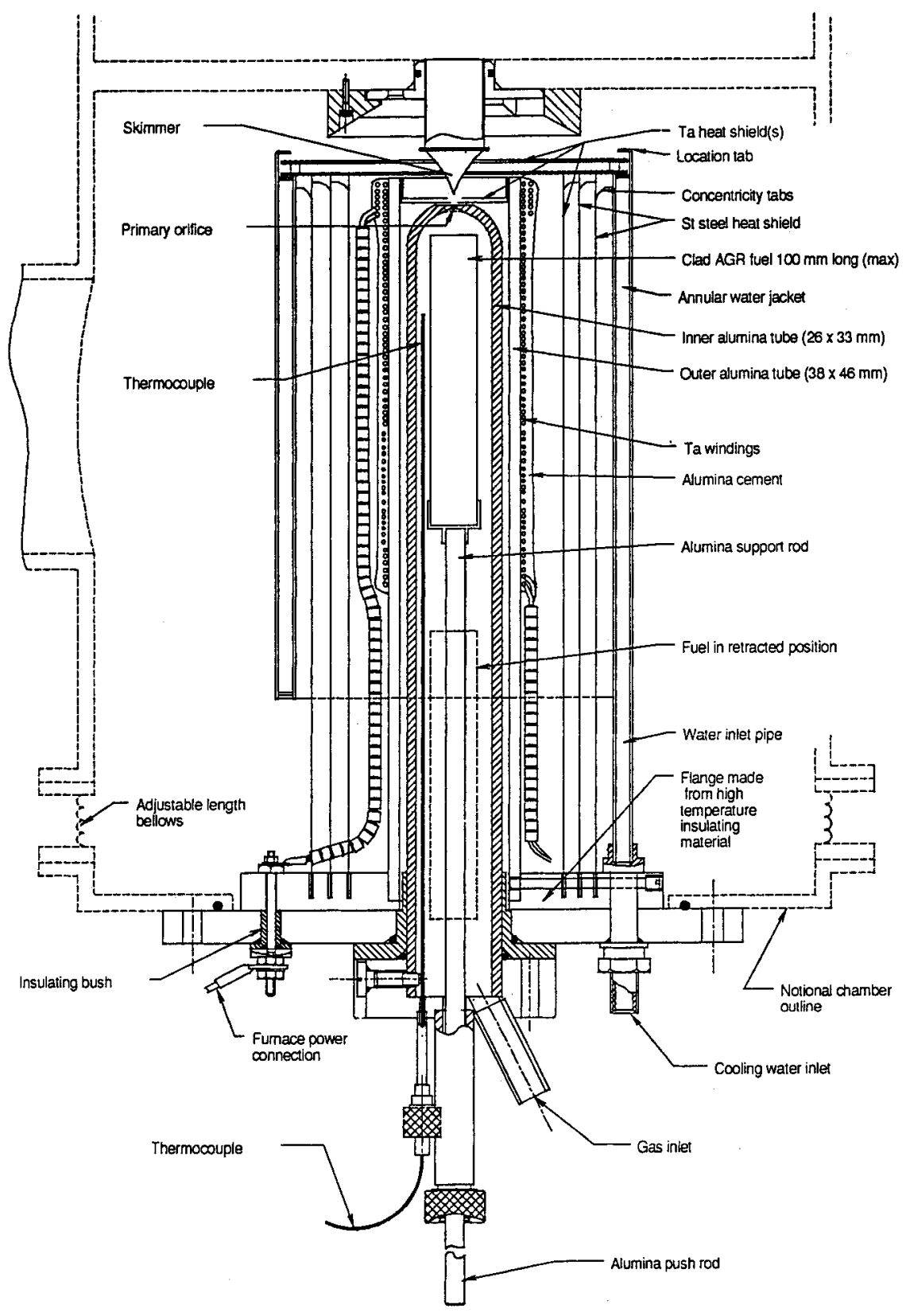

Fig. 1, Osprey Facility

1. A precision furnace capable of attaining temperatures of up to $1600^{\circ} \mathrm{C}$, with plans to extend this to $2000^{\circ} \mathrm{C}$ next year;

2. Provision for a range of atmospheres of different compositions;

3. A pressure reduction system that enables the vapor-phase species to be sampled on-line and at ambient pressure;

4. A Jordan reflectron time-of-flight mass spectrometer that combines sensitivity with scanning of the full mass range of species of interest;

5. Fast data scanning and acquisition to optimise on-line measurements;

6. Time-dependent sampling of material for analysis using $\gamma$-spectroscopy;

7. Containment in a shielded high-active cell to enable handling of highly active samples. 
Scanning of the entire mass range using a time-of-flight mass spectrometer is much faster than for a quadrupole or magnetic sector instrument; for this application the faster speed eliminates the need to examine pre-selected peaks in the spectrum. Therefore this feature, combined with comparable sensitivity, makes it less likely that important species will be omitted from the measurements. The flexibility of the system is such that it can be readily adapted to accommodate samples of different geometry.

The Osprey studies are supported by separate-effect experiments on non-radioactive simulants employing matrix isolation infrared spectroscopy and mass spectrometry used in combination. Figure 2 shows how this is achieved (7). The sample is contained in a silica holder (A) mounted in the centre of a water-cooled jacket (B). An appropriate gas is admitted to the sample via inlet $(C)$, and sample heating is achieved by a simple resistance furnace (D). Two small holes (E, approximately $10 \mu \mathrm{m}$ diameter) in the central sample chamber provide the source of two diametrically opposed molecular beams, which enter the differentially pumped region before passing through further pinholes ( $\mathrm{F}$, approximately $40 \mu \mathrm{m}$ diameter) and sliding gate valves $(G)$, and ultimately into the mass spectrometer and cryostat chambers. These are maintained at a pressure of typically $10^{-5} \mathrm{~Pa}$ using separate pumping systems $(\mathrm{H}, \mathrm{I})$ each comprising an oil diffusion pump backed by a rotary pump and incorporating a liquid nitrogen trap. The whole of the central vacuum shroud is constructed in glass, which permits visual inspection of the experiment, easy cleaning and the insitu unblocking of pinholes by a standard high frequency "Tesla" discharge coil. The matrix gas flow is controlled by a needle valve (J), and species for infrared investigation are co-condensed onto a caesium iodide or silicon window $(\mathrm{K})$ held at ca. $12 \mathrm{~K}$ by a closed-cycle cyrogenic cooler $(\mathrm{L})$. A cross-beam axis mode of sampling is employed for mass spectrometric monitoring so as to minimise contamination of the quadrupole analyser. Two infrared spectrometers are used for these experiments: a Perkin-Elmer $983 \mathrm{G}$ model and a Bruker IFS-113v. The accessible spectral range thus extends well into the far infrared. The mass spectrometers routinely used are a Vacuum Generators 12-12S quadrupole (1-2000 amu) interfaced with an IBM-AT compatible personal computer acting as a data station, and a lower resolution VG SXP600 quadrupole.

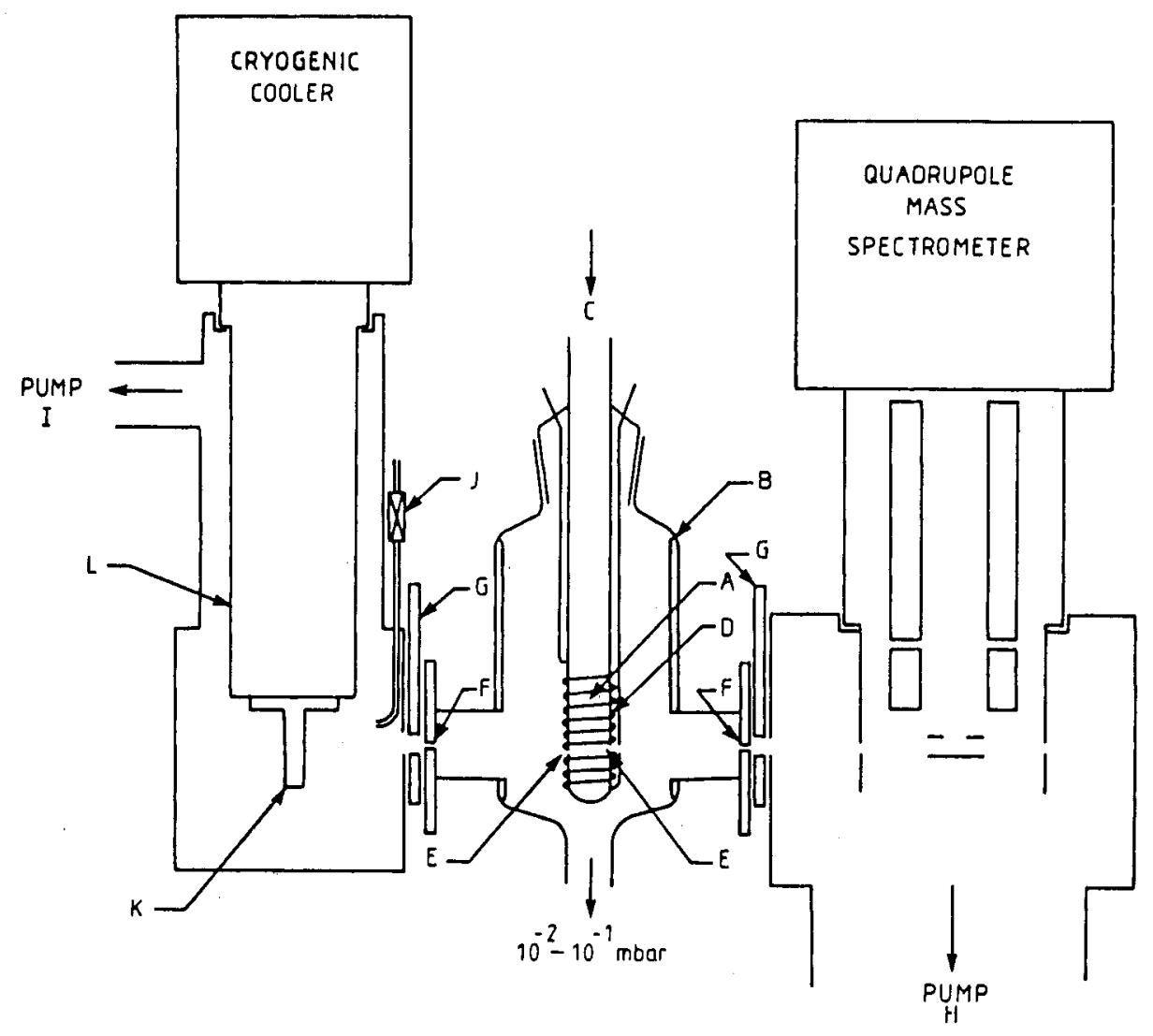

Fig. 2, Combined Matrix Isolation Mass Spectrometry System 


\section{Harrier}

An induction furnace facility is used to heat and contain kilogramme quantities of molten metal. Various waste streams can be processed within this high temperature environment. Harrier is a versatile facility with a variety of configurations and downstream instruments to analyze off-gases. Typical features of a representative arrangement (using a graphite susceptor/crucible) are shown in Figure 3 and described below.

The graphite crucible is located within a single turn radio-frequency concentrator. Two vertical feed pipes supply cooling water to the concentrator from the base plate. The crucible is supported from the base plate using an alumina tube located on, and concentric to, the sump liner. Inserted into the top of the alumina tube is a closed end graphite tube. This tube supports the crucible and acts as a radiant heat shield. In the event of the crucible failing, the closed end of the graphite tube is sufficiently thin that it will break and allow the molten metal to be caught in the sump.

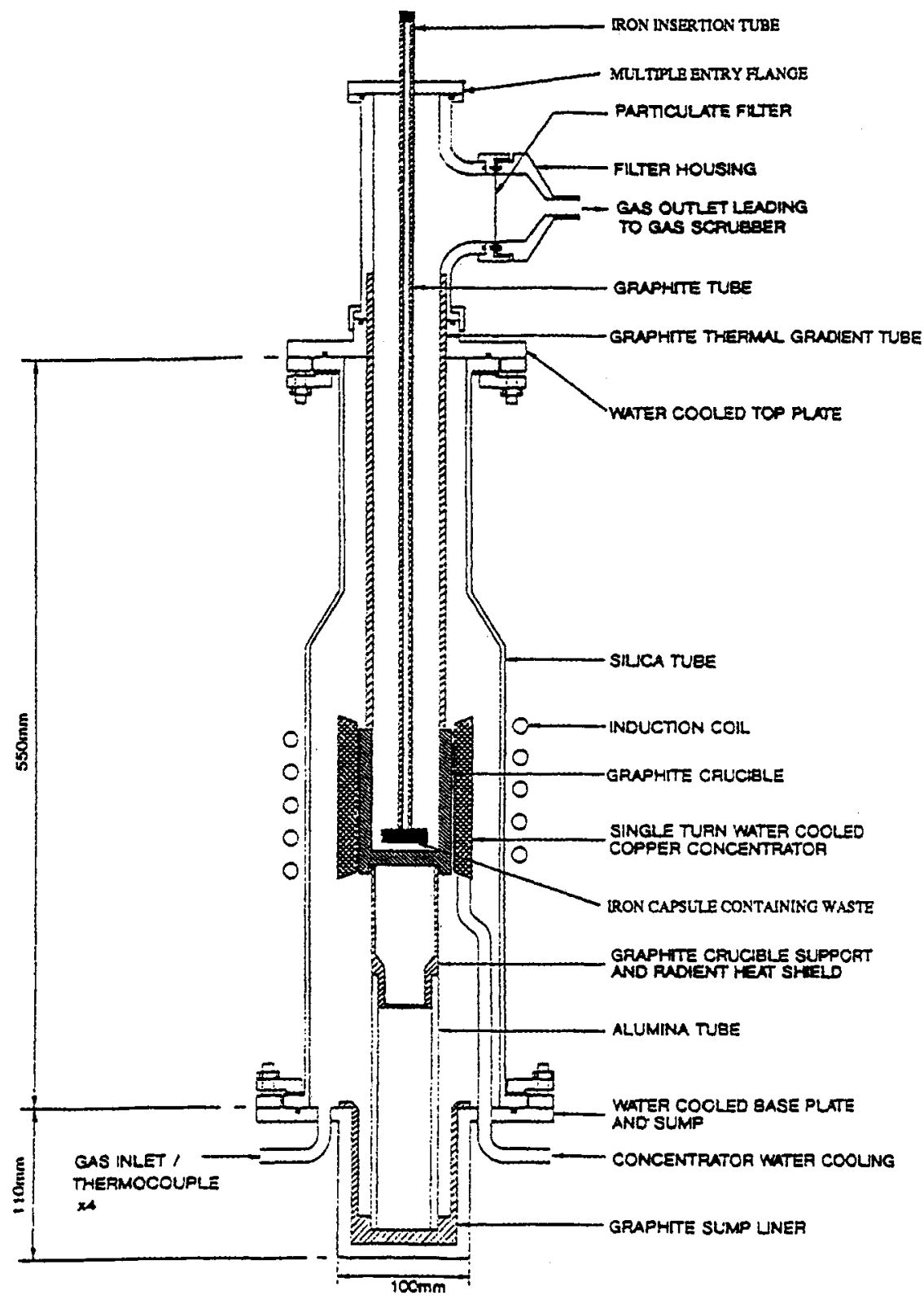

Fig. 3, Harrier Facility 
The top of the silica tube is fitted with a water-cooled metal top plate through which a graphite thermal gradient tube (TGT) is inserted. The lower end of the TGT rests on the top of the crucible, and is castillated to allow an exit for the buffer gas introduced through the base plate. Fitted over the top of the TGT and sealed to the top plate is a metal T-piece. The top of the T-piece is fitted with a multiple entry flange, through which thin metal insertion tubes loaded with waste capsules are passed. This flange also allows a thermocouple well to be inserted into the gas flow. If appropriate, gases can be passed through the central insertion tube. Paddles can be added if required and the insert tube rotated if enhanced mixing is required. The T-piece side arm is fitted with three filters, a main exhaust and two analytical ports, fitted with Nuclepore filters (note this additional detail is not illustrated in Figure 3). Condensed vapors and aerosol released from the melt are collected on the TGT and downstream filters. The exhaust gas passes through a mass spectrometer and/or $\mathrm{CO} / \mathrm{CO}_{2}$ infrared gas analyzer and finally through a gas scrubber. During operation, the furnace is purged with argon at $1.5-2.01 \mathrm{~min}^{-1}$.

Generally eight Nuclepore filters are used to sample the aerosol content of the off-gas during an experiment, so as to provide time-dependent information on the amount of material vaporised and the size distribution and composition of the condensed aerosol. A typical sampling regime would alternate long (high density deposits for mass balance and composition data) and short (low density deposits for particle size and morphology) duration sampling periods.

On completion of each experiment a range of post-test analytical methods is used to acquire information on the partitioning of waste material between the metallic and oxidic phases and the gas phase and to characterise the nature of the gas-phase (vapor/aerosol) release. The methods used include:

(a) Sampling and chemical/radiochemical analysis of metal phase and vitreous phase to quantify residual material.

(b) Sectioning of TGT liner followed by washing and chemical/ radiochemical/microscopic analysis to obtain deposition profiles.

(c) Washing of furnace walls and exit trap followed by chemical and radiochemical analysis of solutions to obtain mass balance information.

(d) Microstructural analysis of collected aerosol samples for particle morphology and composition (eg. fully automated particle recognition and characterization with SEM/EDS, XPS, XRD, etc).

(e) Sectioning of the refractory crucible to examine extent of corrosion.

Advanced thermal analysis methods are also used in conjunction with the main Harrier experiments to acquire materials and chemical compatibility data. These include DTA/TG/EGA up to $1500^{\circ} \mathrm{C}$ and differential scanning calorimetry to $1400^{\circ} \mathrm{C}$. The DTA/TG apparatus has been modified to enable the reaction of high temperature corrosive gases to be studied, and can be used to follow the kinetics of high temperature vapour surface reactions.

\section{TREATMENT OF HIGHLY RADIOACTIVE WASTE}

High temperature chemistry methods have shown particular promise for treating highly radioactive waste, with the potential to concentrate the waste material, and isolate the transurannic waste in a non-leachable form for contact-based disposal. There is a large amount of such highly radioactive material for treatment worldwide as a result primarily of nuclear energy and weapons production programs. For example, the USDOE has announced its plans to privatise the treatment of waste stored at its Hanford site. Over 50 million gallons of high level and transurannic waste is stored at Hanford as a consequence of plutonium production for application in weapons programs.

Some of the experimental technologies described earlier have been applied to examine the partitioning behaviour of such wastes in a molten metal/oxide environment and to quantify the nature of the gas-borne emissions. 


\section{TREATMENT OF UF 6}

The USDOE currently has more than 550 million kilograms of depleted UF $_{6}$ in storage dating from when the Department began operating enrichment plants nearly 50 years ago (4). The United States Enrichment Corporation (USEC) generates 15 million kilograms of depeleted $\mathrm{UF}_{6}$ annually, with the world market for processing spent $\mathrm{UF}_{6}$ estimated to be greater than $\$ 5 \mathrm{~B}(4)$.

Treatment of such waste material in a molten metal bath offers potential in producing environmentally stable uranium compounds such as $\mathrm{UO}_{2}$ or very dense uranium alloy products and other commercial materials such as anhydrous HF. One of the issues associated with such work is the identification of suitable fluxes to separate the $\mathrm{UO}_{2}$ product from waste streams. The criteria for such a flux include: adequate solubility, low density, inmiscibility with metal, and compatibility with the containment material.

Candidate oxide fluxes were considered by a series of thermodynamic calculations which were performed using the computer code MTDATA (9) to determine the equilibrium composition for various oxide systems in the temperature range 1200 to $1600^{\circ} \mathrm{C}$. The thermodynamic data for all the species in the system are stored in databases used by the code which then minimises the total Gibbs energy of the system to determine the chemical equilibrium. Work undertaken by AEA Technology and the National Physical Laboratory as part of a MIRO (Mineral Industry Research Organisation) programme has resulted in the development of a database for oxide materials (10) which has been extended to include $\mathrm{UO}_{2}-\mathrm{Al}_{2} \mathrm{O}_{3}-\mathrm{SiO}_{2}$ $\mathrm{CaO}-\mathrm{Fe}-\mathrm{O}-\mathrm{B}_{2} \mathrm{O}_{3}$. This database comprises available thermodynamic data for the pure phases and optimised binary and ternary interaction terms required to reproduce the experimental phase diagrams. The database can be used in conjunction with other existing databases, such as the SGTE Pure Substance database to calculate detailed phase equilibria in complex systems.

The assessments highlighted the lack of data on the $\mathrm{B}_{2} \mathrm{O}_{3}-\mathrm{UO}_{2}$ system. Hence, experiments were conducted using an adapted version of the Harrier facility described above. Pre-treated $\mathrm{B}_{2} \mathrm{O}_{3}$ (dried at $400^{\circ} \mathrm{C}$ ) was heated within a platinum crucible with an excess of urania. (pre-treated under hydrogen to ensure correct stoichiometry) at temperatures in the range from $1200^{\circ} \mathrm{C}$ to $1600^{\circ} \mathrm{C}$. Once at the required temperature, a filtered tantalum sampling tube was lowered into the mixed melt and used to extract a small liquid sample. The tantalum tubes were then analyzed for urania content of the previously molten phase. These experiments were supported by DTA/TG and DSC studies together with microstructural analyses of rapid-quench samples. On the basis of these experiments, some estimated interaction terms could be introduced into the database described above in order to reproduce the experimental data and enable further calculations to be made.

\section{CONCLUSIONS}

High temperature chemical aspects of waste disposal and environmental clean-up are reviewed. Emphasis is placed on experimental information using two main facilities:

Osprey: to characterise high temperature vapors

Harrier: to quantify the treatment of radioactive wastes in a molten metal environment

These facilities are supported by a wide range of experimental and modeling capabilities. Examples of treatment of various radioactive waste streams are described.

\section{ACKNOWLEDGEMENTS}

The authors wish to thank Chris Benson, Paul Mason, Mike Mignanelli, Mike Newland, and Bob Williamson for their involvement in this work and constructive comments on this paper. 


\section{REFERENCES}

1. T. T. Shen, 'Hazardous Waste Incineration Technologies and Emission Control', in "Hazardous Waste: Detection, Control, Treatment", (Ed. R. Abbou), Elsevier, Amsterdam, p1389 (1988).

2. 'Treatment of Off-Gas from Radioactive Waste Incinerators', IAEA, Vienna (1989).

3. C. Eid and A. J. Van Loon, "Incineration of Radioactive Waste", CEC (1988).

4. M. Valenti, 'Ironing Out Industrial Wastes', Mech. Eng., 106 (1996).

5. C. A. Stearns, F. J. Kohl, G. L Fyburg and R. A. Miller, NBS Special Publication No 561, 303 (1979).

6. C. G. Benson, B. R. Bowsher et al, AEAT-Report 1084 (1997).

7. B. R. Bowsher, A. K. Brisdon, S. Dickinson and J. S. Ogden, in Fission Product Transport Processes in Reactor Accidents, (Ed. J. T. Rogers), p137, Hemisphere, New York (1990).

8. Differential Thermal Analysis (Ed. R. C. MacKenzie), Academic Press Inc. (London) (1970).

9. T. I. Barry, R. H. Davies, A. T. Dinsdale and M. Laney, "MTDATA Handbook: NPL Databank for Metallurgical Thermochemistry" (1989).

10. R. G. J. Ball, M. A. Mignanelli, T. I. Barry and J. A. Gisby, J. Nucl. Mats. 201, 238 (1993). 